\title{
PENGUATAN MANAJEMEN PUSAT KEGIATAN BELAJAR MASYARAKAT DALAM MENINGKATKAN MUTU LAYANAN PENDIDIKAN NONFORMAL
}

\author{
Asep Saepudin, Ade Sadikin,\& lip Saripah \\ e-mail: aspudin@gmail.com \\ PLS FIP Universitas Pendidikan Indonesia \\ JI. Dr. Setiabudhi No. 229 Bandung
}

\begin{abstract}
Abstrak: Penelitian ini bertujuan untuk (1) mendeskripsikan model konseptual layanan PKBM, (2) melakukan validasi model konseptual layanan PKBM, dan (3) menganalisis implementasi model layanan PKBM. Penelitian ini menggunakan pendekatan kualitatif dengan metode deskriptif. Teknik pengumpulan data yang digunakan dalam studi ini terdiri atas: studi dokumentasi, studi literatur, wawancara, dan kelompok diskusi terfokus (FGD). Subjek penelitiannya adalah pengelola dan tutor, serta peserta didik PKBM yang berada di wilayah Bandung Raya yang dilakukan pada April - September 2015. Hasil penelitian berupa (1) model konseptual yang dikembangkan terdiri atas, rasionalisasi, asumsi, tujuan, komponen, indikator, dan prosedur model; (2) validasi model dilakukan dengan menggunakan dua cara yakni diskusi dengan teman sejawat (peer group) dan penilaian para ahli (expert judgement); serta (3) implementasi model dideskripsikan dalam kegiatan pembelajaran di PKBM. Langkah-langkah pembelajaran sebagai komponen model adalah proses perencanaan, pengorganisasian, pelaksanaan dan penilaian dalam pembelajaran. Kesimpulan model yang dikembangkan menunjukkan hasil yang efektif, dengan indikator (a) adanya keterlibatan aktif dan tanggapan positif warga masyarakat terhadap kegiatan pembelajaran, serta (b) hasil belajar warga msyarakat menunjukkan terdapat peningkatan kemampuan pengetahuan, sikap dan keterampilan.

Kata-kata Kunci: penguatan manajemen, PKBM, mutu layanan, pendidikan nonformal.
\end{abstract}

\section{STRENGTHENING THE MANAGEMENT OF COMMUNITY LEARNING CENTER TO IMPROVE THE SEVICE QUALITY OF NON-FORMAL EDUCATION}

\begin{abstract}
The purposes of this research are (a) to describe service conceptual model of Community Learning Center (CLC), (b) to validate the service conceptual model of CLC, and (c) to analyze the implementation of the service conceptual model of CLC. The research employed qualitative approach and descriptive method. The data were collected by using document study, literature review, interview, and Focus Group Discussion as from April through September 2015. The subjects of the study included administrators, tutors, and CLC participants in Bandung Raya area. The research resulted in (a) the developed conceptual model consisting of rationalization, assumption, objectives, components, indicators, and procedure model; (b) the model validation used peer group and expert judgement techniques; and model implementation described in instructional activities in CLC. Instructional steps as the model components are planning process, organizing, implementation, and evaluation in instruction. The conclusion of the developed model indicates effective results with the indicators: (a) the active participation and respond of the community for instructional activities and (b) the learning achievement of the community shows the improvement in knowledge, attitude, and skills.
\end{abstract}

Keywords: strengthening management, Community Learning Center, nonformal education.

\section{PENDAHULUAN}

Perkembangan ilmu pengetahuan dan teknologi telah melahirkan percepatan perubahan di segala bidang, yang mempengaruhi sendi- sendi kehidupan manusia. Menyikapi perubahan perkembangan dunia yang semakin mengglobal, UNESCO menerapkan empat pilar belajar, yaitu 
learning to know, learning to do, learning to live together, dan learning to be. Pada learning to know terkandung makna bagaimana belajar, learning to do mengandung dimensi kecakapan hidup manusia, learning to live together mengandung dimensi kehidupan multikultural, dan learning to be mengandung makna belajar untuk mengenal jati diri, kemampuan dan kelemahan serta kompetensi yang dikuasai untuk membangun kehidupan yang utuh secara terus-menerus.

Penerapan empat pilar belajar UNESCO (2005), yaitu learning to know, learning to do, learning to live together, dan learning to be, melahirkan konsep revolusi belajar. Model pembelajaran modern, yaitu melatih para peserta didik untuk menjadi sumber belajar, mengubah model belajar pasif (passive learning) menjadi belajar aktif (active learning), mengubah model berpikir fakta (factual thinking) menjadi berpikir kritik (critical thinking), dari kurang aktif memberi respons menjadi proaktif memberi respons, dari berpikir abstrak menjadi autentik. Perubahan ini, menempatkan peranan pendidikan nonformal dalam posisi yang strategis. Menurut Sihombing (1999:12) pendidikan luar sekolah bukan hanya sebagai lembaga pendidikan dalam masyarakat tetapi juga merupakan program strategis yang responsif dalam menanggulangi permasalahan yang dihadapi masyarakat.

Berdasarkan alur pemikiran di atas, implementasi program belajar dalam PKBM merupakan pendekatan pendidikan (educational approach) pada jalur pendidikan nonformal yang didasarkan kepada konvergensi kebutuhan belajar (learning needs) dengan sumber belajar (learning resourch) dalam masyarakat, yang membentuk suatu sistem belajar. Sebagai suatu sistem belajar PKBM dibangun atas lima komponen berikut: (1) kebutuhan belajar, (2) sumber belajar, (3) program pembelajaran, (4) kelompok belajar/wadah pembelajaran, dan (5) fasilitator kegiatan belajar.

Terminologi yang berkaitan dengan PKBM yaitu: Pusat, bermakna pemusatan manajemen, bukan dalam pengertian pemusatan berbagai program layanan PKBM pada satu tempat. Pemusatan manajemen penyelenggaraan PKBM, terutama dalam hal pemecahan masalah dan pendayagunaan sumberdaya. Kegiatan belajar, setiap program atau kegiatan layanan PKBM diselenggarakan dalam setting pembelajaran sehingga proses dan hasil program dan kegiatan layanan yang diikuti dan diperoleh warga sasaran program harus berdampak kepada perubahan pengetahuan, sikap dan keterampilan. Masyarakat, merupakan sasaran utama dan sasaran akhir dari setiap program/ kegiatan layanan yang dirancang oleh PKBM. Pada sisi lain masyarakat juga merupakan sasaran utama dan sasaran akhir dari fasilitasi dan pendampingan yang dilakukan oleh pihak luar. Menurut Hikmat, $\mathrm{H}$., (2001:23), fasilitasi dan atau pendampingan dari pihak luar masyarakat dan keterlibatan masyarakat dalam penyelenggaraan PKBM diorientasikan kepada penguatan kemampuan masyarakat berperan aktif: (1) sebagai penyelenggara atas upaya pemenuhan kebutuhan pembelajarannya; (2) dalam setiap proses pengambilan keputusan yang menyangkut dengan upaya peningkatan taraf hidup dan kehidupannya; dan (3) sebagai penggagas serta penggerak bagi dirinya sendiri maupun masyarakat lain di lingkungan sekitarnya.

Mengingat karakteristik dan trend permasalahan pendidikan nonformal saat ini mengarah kepada penanganan kebutuhan nyata masyarakat, maka orientasi program PKBM sebagai satuan pendidikan nonformal diproyeksikan pada pendidikan masyarakat dengan pendekatan Community Based Education (CBE). Menurut Fasli Jalal dan Dedi Supriadi (2001:31) Community Based Education menekankan pentingnya pemahaman masyarakat, karakteristiknya, kebutuhannya, kelemahan dan kekuatan yang dimilikinya. Dalam implementasinya CBE merupakan metode yang menekankan pada cara pemecahan masalah oleh masyarakat, dengan memanfaatkan potensi lingkungan (to help people to help them self). Community Base Education, dikembangkan bersandar kepada beberapa konsepsi sebagai berikut: Pendidikan sepanjang hayat, Pendidikan kritis yang menekankan perbaikan kemampuan dasar masyarakat, meningkatkan kemampuan yang ada, serta partisipasi dalam setiap kegiatan, Andragogi, dan Learning Organization.

Berdasarkan data empiris, PKBM di wilayah Bandung Raya merupakan PKBM yang telah teruji mampu meningkatkan sumber daya manusia yang bermutu. Program pendidikan yang diselenggarakan PKBM umumnya adalah program pendidikan kesetaraan paket $A$, paket $B$, dan paket $C$. Program pendidikan anak usia dini, program pendidikan life skill (kursus keterampilan), dan pendidikan masyarakat lainnya yang diselenggarakan sesuai dengan kebutuahan dan potensi lingkungan 
masarakat sekitar. Namun demikian, PKBM di wilayah Bandung Raya rata-rata belum sepenuhnya menyelengaraan pendidikan sesuai standar nasional pendidikan. Hal ini dikarenakan belum seluruhnya PKBM memiliki kelayakan dilihat dari aspek manajemen penyelenggaraan, standarisasi dan ketertiban administrasi dan kelayakan fisik lembaga sebagai penyelenggara pendidikan.

Sejalan dengan uraian di atas, pada sisi lain, upaya untuk mengembangkan pendidikan nasional baik melalui jalur pendidikan formal maupun pendidikan nonformal terus ditingkatkan secara berkelanjutan sebagai implementasi dari komitmen pemerintah untuk menyelenggarakan pendidikan bermutu sebagaimana diamanatkan dalam pembukaan Undang-undang Dasar 1945, serta Undang-undang Sistem Pendidikan Nasional No. 20 tahun 2003. Kebijakan tentang optimalisasi pendidikan nonformal juga dperkuat dengan Peraturan Pemerintah No.73 tahun 1991 tentang pendidkan luar sekolah. Oleh karena itu, sangat beralasan apabila PKBM sebagai salah satu satuan pendidikan nonformal mendapat perhatian lebih dan untuk terus diperkuat sebagai lemaga pendidikan yang telah teruji mampu memberdayakan masyarakat melalui berbagai program pendidikan sesuai kebutuhan masyarakat.

Berdasarkan alur pemikiran di atas, maka dilakukan penelitian ini dalam rangka untuk penguatan manajemen PKBM di wilayah Bandung Raya. Harapan besar manfaat dari penelitian ini adalah mampu mengungkap secara empiris terhadap ragam pengelolaan $\mathrm{PKBM}$, standar minimal penyelenggaraan PKBM, dan upaya merumuskan desain konseptual layanan PKBM bermutu yang dibutuhkan masyarakat khsusnya di wilayah Bandung Raya.

Peneltian ini mengusung kajian teori yang relevan dengan tema penelitian yakni berkenaan dengan: (1) konsep pendidikan luar sekolah, (2) konsep, tujuan, prinsip, karakteristik, program, standar minimal, serta pengembangan evaluasi PKBM.

Konsep pendidikan luar sekolah sebagai salah satu sub sistem pendidikan nasional memiliki ruang lingkup yang sangat luas dan komplek. Secara teoretis, Sudjana dalam Saepudian (2015:95) mendefinisikan pendidikan luar sekolah sebagai kegiatan terorganisasi dan sistematis, di luar sistem persekolahan yang mapan, dilakukan secara mandiri atau merupakan bagian penting dari kegiatan yang lebih luas, yang sengaja dilakukan untuk melayani peserta didik tertentu di dalam mencapai tujuan belajarnya.

Konsep PKBM sebagai satuan pendidikan luar sekolah mengemuka sejak awal tahun 1990 an, yang dipopulerkan lewat suatu pertemuan para pimpinan negara di dunia. Dalam studinya Jajat S. Ardiwinata (2014: 100) menjelaskan bahwa dalam deklarasi Dunia tentang Education For All (EFA), di Jomtien, Thailand tahun 1990, hampir 155 negara menggagas adanya Community Learning Centre (CLC) sebagai cikal bakal munculnya istilah PKBM di Indonesia. Sihombing dan Gutama (2000:34) memaparkan PKBM adalah sebuah lembaga pendidikan yang dikembangkan dan dikelola oleh masyarakat serta diselenggarakan di luar sistem pendidikan formal baik di perkotaan maupun di pedesaan dengan tujuan untuk memberikan kesempatan belajar kepada seluruh lapisan masyarakat agar mampu membangun dirinya secara mandiri sehingga dapat meningkatkan kualitas hidupnya. Untuk itulah, PKBM berperan sebagai tempat pembelajaran masyarakat terhadap berbagai pengetahuan atau keterampilan dengan memanfaatkan sarana, prasarana dan potensi yang ada di sekitar lingkungannya (desa, kota), agar masyarakat memiliki keterampilan yang dapat dimanfaatkan untuk meningkatkan taraf hidup dan prestasi belajar masyarakat. Berkenaan dengan itu, masyarakat berprestasi adalah masyarakat yang mau belajar. Laila Hayati (2011:181) dalam hasil penelitiannya menyimpulkan bahwa prestasi tidak akan pernah dihasilkan selama seseorang tidak pernah melakukan kegiatan belajar.

Tujuan penting dalam pengembangan PKBM menurut Sihombing dan Gutama (2000: 36) adalah pertama, memberdayakan masyarakat agar mampu mandiri (berdaya). Kedua, meningkatkan kualitas hidup masyarakat baik dari segi sosial maupun ekonomi. Ketiga, meningkatkan kepekaan terhadap masalah-masalah yang terjadi dilingkungannya sehingga mampu memecahkan permasalahan tersebut. Sihombing (1999) menyebutkan bahwa tujuan pelembagaan PKBM adalah untuk menggali, menumbuhkan, mengembangkan, dan memanfaatkan seluruh potensi yang ada di masyarakat itu sendiri. Dalam arti memberdayakan seluruh potensi dan fasilitas pendidikan yang ada di desa sebagai upaya membelajarkan masyarakat 
yang diarahkan untuk mendukung pengentasan kemiskinan, dengan prinsip pengembangan dalam rangka mewujudkan demokrasi bidang pendidikan.

Tujuan lain dari penyelenggaraan program pendidikan di PKBM adalah untuk meningkatkan kompetensi warga masyarakat sehingga memiliki keterampilan dalam memecahkan permasalahan yang dihadapi selama hidupnya. Kompetensi dimaksud hanya akan diperoleh lewat proses belajar yang diarahkan untuk meningkatkan pengetahuan, sikap dan keterampilan. Menurut Oos M. Anwas (2011:193), kompetensi adalah kemampuan yang dilandasi oleh pengetahuan, keterampilan, dan didukung oleh sikapnya yang dituntut dalam melaksanakan tugas pekerjaannya. Ini berarti hanya masyarakat yang mau belajar yang akan memiliki kompetensi. Salah satu sarana peningkatan kompetensi yang relevan dengan kebutuhan masyarakat adalah melalui belajar pada satuan pendidikan PKBM.

Menurut Sihombing. (1999:12) beberapa prinsip dasar yang dapat dijadikan acuan dalam pengembangan dan menyusun program PKBM antara lain adalah: a) program yang dikembangkan PKBM harus meluas sehingga warga belajar memperoleh kesempatan yang luas untuk mengembangkan pengalaman tentang pengetahuan, keterampilan, sikap dan nilai yang berkaitan dengan etika, estetika, logika dan kinestetika pada saat pembelajaran; b) program harus memiliki prinsip keseimbangan (balanced) dimana setiap kompetensi yang dikembangkan dalam program PKBM harus dicapai melalui alokasi waktu yang cukup untuk sebuah proses pembelajaran yang efektif; c) program yang dikembangkan PKBM harus relevan karena setiap program terkait dengan penyiapan warga belajar untuk meningkatkan mutu kehidupan melalui kesempatan, pengalaman, dan latihan dalam berperan dan bersikap secara bertanggung jawab dalam mewujudkan kedewasaan berpikirnya, d) program yang dikembangkan PKBM harus mampu mengedepankan konsep perbedaan (differentiated), prinsip ini merupakan upaya pelayanan individual dimana warga belajar harus memahami: apa yang perlu dipelajari; bagaimana berpikir, bagaimana belajar, dan berbuat untuk mengembangkan potensi dan kebutuhan dirinya masing-masing secara optimal.

Dalam upaya untuk menjalankan prinsip PKBM sehingga selaras dengan kepentingan dan kemampuan masyarakat, maka perlu dikembangkan standar minimal manajemen penyelenggaraan PKBM yang berbasis masyarakat (community based). Tujuan dikembangkannya standar minimal PKBM Standar \& Prosedur Penyelenggaraan PKBM (Kementerian Pendidikan dan Kebudayan, 2015:3) adalah: (a) PKBM yang telah terbentuk dapat menyelaraskan dan menyesuaikan proses penyelenggaraannya dengan segenap potensi dan sumber daya disekitarnya dan sekaligus memberikan wawasan terhadap kepentingan pembangunan yang lebih luas; dan (b) Dapat dijadikan salah satu alat fasilitasi aparat pemerintah dalam pembentukan PKBM oleh masyarakat.

Lingkup Standar Minimal PKBM diukur berdasarkan 8 (delapan) standar nasional pendidikan sebagaimana tercantum dalam Peraturan Pemerintah No. 19 tahun 2005. Kedelapan aspek tersebut yakni: (1) standar isi, (2) standar proses, (3) standar lulusan, (4) standar pendidik, (5) standar sarana prasarana, (6) standar pengelola, (7) standar penilaian, (8) standar pembiayaan (Pedoman Evaluasi Dikmas, 2014:3). Merujuk kepada fungsi utama dan pendukung PKBM, paling tidak ada empat bidang kegiatan yang perlu dikelola oleh Pengelola PKBM. Bidang kegiatan tersebut adalah: pertama, Pendidikan, meliputi kegiatan pembimbingan atau penyuluhan, pengajaran dan pelatihan. Kedua, Pelayanan informasi, meliputi kegiatan: (1) Menghimpun informasi dari PKBM, masyarakat sekitar, dan lembaga luar, (2) Memberikan layanan informasi kepada masyarakat sekitas dan lembaga luar. Ketiga, Jaringan informasi dan kemitraan, meliputi kegiatan: (1) Mengembangkan jaringan informasi dan kemitraan dengan lembaga yang ada di dalam maupun di luar masyarakat dalam penyelenggaraan kegiatan di PKBM maupun di lembaga mitra. (2) Memelihara jaringan yang telah terbina, dan Keempat, Pembinaan tenaga kependidikan PKBM, meliputi kegiatan: meningkatkan kualitas kinerja tenaga pengelola dan tenaga pendidik (tutor, nara sumber) baik dilakukan secara mandiri maupun atas fasilitasi dari luar.

Berkenaan dengan standar minimal penyelenggaraan PKBM, dalam buku Standar \& Prosedur Penyelenggaraan PKBM (2015:3) ditegaskan bahwa berdasarkan fungsi PKBM yang terbagi atas standar manajemen dan standar fisik (sarana dan prasarana), meliputi: pertama, Standar minimal manajemen, menguraikan kegiatan minimal 
yang perlu dilakukan oleh pengelola PKBM agar fungsi PKBM dapat dilaksanakan. Kegiatan-kegiatan pengelolaannya diuraikan berdasarkan tahapan perencanaan, pengorganisasian, pelaksanaan dan pengendalian, dan penilaian. Kedua, Standar minimal sarana fisik, menguraikan sarana dan prasarana penunjang minimal yang perlu disiapkan oleh pengelola untuk digunakan dalam pengelolaan kegiatan PKBM.
Berdasarkan paparan diatas, penyelenggaraan pendidikan dan PKBM sebagai wadah untuk peningkatan seluruh lapisan anggota masyarakat melalui jalur pendididkan nonformal diperkirakan belum seluruhnya dapat memenuhi harapan sebagai bagian dari pendidikan berbasis masyarakat, karena faktor penunjang maupun kemampuan internal yang belum memadai.

\section{METODE PENELITIAN}

Penelitian ini menggunakan pendekatan kualitatif dengan metode deskriptif, sehubungan penelitian ini mengungkap tentang fenomena empirik saat ini (Sugiyono, 2011:3). Subjek penelitian yang dijadikan sumber data utama adalah unsur pengelola PKBM, dan unsur Dinas Pendidikan di wilayah Bandung Raya yakni di wilayah Kota Bandung, Kabupaten Bandung, dan Kabupaten Bandung Barat. Masing-masing wilayah diwakili oleh empat PKBM. Pada masing-masing Kabupaten/Kota ditentukan sampelnya 1 (satu) satuan PKBM berdasarkan wilayah yakni: bagian utara, bagian selatan, bagian barat dan bagian timur. Agar penelitian dapat terfokus dan dilakukan secara mendalam maka yang menjadi subjek penelitian/informan dibatasi jumlahnya dengan pertimbangan informan tersebut memiliki informasi yang dibutuhkan peneliti, dalam hal ini peneliti menggunakan purpose sampling dalam teknik pengambilan sampling. Sebagaimana yang disebutkan Sugiyono (2012:301) bahwa "Purpose Sampling adalah teknik pengambilan sampel sumber data dengan pertimbangan tertentu". Dengan demikian, dari setiap satuan PKBM, dietetapkan ada satu orang pengelola, satu orang unsur sumber belajar/instruktur, dan dua orang warga masyarakat sebagai peserta didik sehingga jumlah informan primer penelitian 12 orang yaitu 3 orang pengelola PKBM dan 3 orang unsur sumber belajar dan 6 warga masyarakat.

Variabel penelitian yang diekplorasi dari subjek penelitian adalah: (1) desain model pengelolaan lembaga PKBM, (2) deskripsi validasi model, dan (3) implementasi model penguatan manajemen PKBM. Teknik pengumpulan data yang digunakan yaitu dengan teknik observasi, wawancara, dokumentasi dan angket. Selanjutnya, analisis data dilakukan dengan beberapa tahap yaitu: (1) reduksi data (data reduction), (2) penyajian data (data display), dan (3) kesimpulan (conclusion drawing/verification). Waktu penelitian dilakukan selama enam bulan, yakni pada bulan April - September 2015.

Langkah-langkah penelitian adalah hal penting yang perlu ditetapkan oleh peneliti. Menurut suharsimi Arikunto (2010:25) dalam kegiatan penelitian sekurang-kurangnya peneliti harus menyusun tahap persiapan, pelaksanaan, dan pelaporan. Untuk itu dalam penelitian ini dilakukan dalam empat tahap yaitu: (a) tahap persiapan (pra lapangan), (b) tahap pekerjaan lapangan (pengumpulan data), (c) tahap analisis data, dan (d) tahap pelaporan.

\section{HASIL DAN PEMBAHASAN}

1. Desain Model Penguatan Manajemen PKBM di Wilayah Bandung Raya.

Model konseptual yang dikembangkan terdiri atas, rasionalisasi, asumsi, tujuan, komponen, indikator, dan prosedur model. Keenam aspek tersebut diuraikan sebagai berikut.

Pertama, rasionalisasi pengembangan model adalah didasari pemikiran bahwa Pusat Kegiatan Belajar Masyarakat (PKBM) merupakan satuan pendidikan luar sekolah yang memliki peran sangat penting dalam pendidikan di masyarakat, terutama di wilayah Bandung Raya. Hal tersebut terbukti dari: (1) animo masyarakat untuk mengikuti pendidikan pada lembaga PKBM sangat tinggi, (2) PKBM telah berhasil menjadi lembaga pendidikan alternatif, yakni sebagai pelengkap (suplemen), pengganti (substitusi) dan penambah (komplemen) pendidikan formal sangat efektif. Pada sisi lain, satuan pendidikan PKBM dalam perkembangannya menghadapi berbagai hambatan terkait dengan kinerja program-program yang dijalankan di dalamnya, diantaranya mutu layanan dan ketersediaan sarana prasarana, pada sebagian besar PKBM selain belum merata juga kondisi 
nya masih relatif kuirang baik sehingga standar mutu PKBM di berbagai wilayah perlu ditingkatkan sebagaimana mestinya. Untuk terjadinya peningkatan produktivitas dan terpenuhinya mutu layanan PKBM, maka diperlukan penataan mutu dan pengelolaan PKBM khususnya di wilayah Bandung Raya melalui intervensi penerapan model penguatan manajemen PKBM dalam meningkatkan mutu layanan pendidikan bagi masyarakat

Kedua, asumsi pengembangan model (1) pengelola PKBM di satu sisi memiliki potensi dan peluang yang dapat dikembangkan dalam pengelolaan PKBM, dan di sisi lain dihadapkan pada berbagai kendala dalam mengembangkan PKBM yakni keterbatasan fasilitas dan kemampuan pengembangan PKBM. Untuk itu pengelola PKBM diharapkan memiliki kompetensi pengelolaan dalam melakukan kegiatan discovery terutama berkaitan dengan kemampuan dan keterampilan memecahkan masalah-masalah yang dihadapinya serta mencoba memperbaiki kekurangan yang dialaminya.

Ketiga, tujuan pengembangan model ini adalah menawarkan sebuah model penguatan manajemen PKBM bagi pengelola, dalam meningkatkan mutu layanan pendidikan kepada masyarakat, yang diorientasikan pada penguatan kompetensi perencanaan, pelaksanaan, dan evaluasi program.

Keempat, komponen model berkaitan dengan prinsip pengelolaan yang dikembangkan dengan mempertimbangkan: (1) sasaran, (2) bahan belajar, dan (3) sumber belajar. Untuk mengembangkan model dirancang seperangkat instrumen yang melengkapi model, yakni: (1) instrumen proses eksploratif dalam mengidentifikasi kebutuhan konstruksi model sebagai landasan pokok merumuskan rancangan model, (2) instrumen proses implementatif model. Sedangkan unsur program model terdiri dari: (1) perencanaan, (2) pengorganisasian, (3) pelaksanaan, dan (4) penilaian.

Kelima, indikator model antaralian: (1) Tumbuhya kesadaran bagi pengelola PKBM (2) Adanya keterlibatan aktif antar pengelola program pendidikan, pendidik dan peserta didik (warga belajar) yang secara bersama-sama merencanakan, mengorganisasikan, melaksanakan dan mengevaluasi kegiatan pembelajaran sesuai permasalahan dan kebutuhan belajarnya, (3) Meningkatnya mutu layanan pendidikan pada satuan PKBM sesuai standar nasional pendidikan.

Keenam, prosedur implementasi model penguatan manajemen PKBM ditempuh melalui empat tahap kegiatan, yakni perencanaan, pengorganisasian, pelaksanaan, dan penilaian (evaluasi).

2. Validasi Model Penguatan Manajemen PKBM di Wilayah Bandung Raya

Dalam upaya menghasilkan model penguatan manajemen PKBM yang efektif, dilakukan pengujian kelayakan model yang telah dikonseptualisasikan (model hipotetik) sebelum diimplementasikan. Kegiatan uji kelayakan model dilakukan melalui dua tahap yakni tahap analisis kualitas model dan tahap penilaian para ahli (expert judgement).

Pertama, tahap analisis model dilakukan dengan cara mengkaji terhadap isi (content) dan keterkaitan dari setiap aspek model. Analisis terhadap model dilakukan oleh peneliti dan didiskusikan dengan teman sejawat. Kegiatan analisis model ini dilakukan secara sistematik, untuk melihat kelayakan model penguatan manajemen PKBM sebagai suatu kesatuan yang utuh, saling berhubungan satu aspek dengan aspek lainnya. Tujuan akhir pada tahap ini adalah selain untuk melihat apakah isi model telah memadai, juga apakah hubungan antar aspek yang dikembangkan telah tepat.

Kedua, tahap penilaian para ahli (expert judgement) dilakukan dengan cara konsultasi dengan para ahli kurikulum pendidikan, ahli komunikasi, dan praktisi PKBM. Para ahli yang dilibatkan dalam penilaian model adalah yang memiliki latar belakang pendidikan yang relevan dengan kebutuhan pengembangan model penguatan manajemen PKBM. Proses penilaian para ahli dilakukan dengan menggunakan teknik respon terinci, dimana peneliti menyampaikan konsep model penguatan manajemen PKBM disertai instrumen yang terintegrasi dalam suatu format kepada para ahli yang telah ditetapkan. Para ahli tinggal mengisi pendapatnya pada kolom yang telah disediakan pada format isian.

3. Implementasi Model Penguatan Manajemen PKBM di Wilayah Bandung Raya

Implementasi model dideskripsikan dalam kegiatan pembelajaran di PKBM. Langkah-langkah pembelajaran sebagai komponen model adalah (a) proses perencanaan, (b) pengorganisasian, (c) pelaksanaan, dan (d) penilaian dalam pembelajaran. 
Pertama, tahap perencanaan merupakan kegiatan awal yang dilakukan oleh pengelola sebelum melaksanakan seluruh kegiatan pembelajaran. Oleh karena itu, pada tahap ini pengelola PKBM selayaknya melakukan perencanaan pembelajaran secara matang dan sistematik. Perencanaan pembelajaran dalam pelaksanaan melibatkan bnayak pihak, teruatama yang terkait dengan kebutuhan dan dampak dari penerapan model ini. Kegiatan perencanan dilakukan melalui empat kegiatan, yakni: (a) identifikasi umum kebutuhan belajar, (b) menetapkan kebutuhan belajar berdasarkan porsi terbanyak, (c) identifikasi sumber belajar, dan (d) identifikasi mitra kerjasama. Kegiatan identifikasi kebutuhan belajar (learning needs) dilakukan terhadap informan awal yang dipandang memiliki kapabilitas dan kredibilitas dalam memberikan informasi untuk mendapatkan gambaran umum tentang kebutuhan belajar.

Kedua, tahap pengorganisasian diarahkan untuk merumuskan perencanaan pembelajaran berkenaan dengan: (a) tujuan pembelajaran yang disesuaikan dengan tujuan umum yaitu peningkatan kemampuan pengetahuan dan keterampilan warga masyarakat dalam meningkatkan kemampuan diri; (b) materi pembelajaran yang diarahkan pada materimateri yang dapat meningkatkan pengetahuan dan keterampilan dalam meningkatkan kemampuan diri warga masyarakat; (c) metode dan teknik pembelajaran yang disesuaikan dengan jenis materi yang dipelajari, apakah menunutut teknik ceramah, diskusi, penugasan atau simulasi; serta (d) media/ alat pembelajaran yang disesuaikan dengan materi yang akan dipelajari.

Ketiga, tahap pelaksanaan merupakan kegiatan pembelajaran diarahkan dalam suasana atau iklim kegiatan yang interaktif, demokratis dan partisipatif. Sumber belajar yang memiliki kesempatan luas untuk menjadi manager sehingga terjadinya transfer pengetahuan dan keterampilan dari dirinya atau pihak lain kepada warga masyarakat sebagai peserta didik dalam kegiatan pembelajaran. Baik secara sendiri atau melibatkan pihak lain, pendamping atau sumber belajar melakukan kegiatan yang diarahkan untuk membantu atau mendampingi terjadinya proses belajar warga masyarakat. Sumber belajar diupayakan untuk meningkatkan kemampuan pengetahuan dan keterampilan warga masayarakat dalam meningkatkan kemampauan diri sesuai kebutuhannya.

Tahap evaluasi dilakukan untuk mengobservasi atau pengamatan terhadap beberapa aspek yang menjadi ukuran dari hasil beajar yang dilakukan oleh warga masyrakat sebagai warga belajar atau peserta didik. Hasil yang diperoleh menunjukan peningkatan nilai skor rata-rata pretest dan post test peserta didik. Selain itu, evaluasi terhadap pengelola relatif menunjukkan respon dan penilaian yang baik dari peserta didik.

\section{PENUTUP}

\section{Kesimpulan}

Kesimpulan hasil penelitian adalah sebagai berikut. Pertama, model konseptual yang dikembangkan terdiri atas, rasionalisasi, asumsi, tujuan, komponen, indikator, dan prosedur model. Kedua, validasi model dilakukan dengan menggunakan dua cara yakni diskusi dengan teman sejawat (peer group) dan penilaian para ahli (expert judgement). Ketiga, implementasi model dideskripsikan dalam kegiatan pembelajaran di PKBM. Langkah-langkah pembelajaran sebagai komponen model adalah proses perencanaan, pengorganisasian, pelaksanaan, dan penilaian dalam pembelajaran.

Kesimpulan model yang dikembangkan menunjukkan hasil yang efektif, dengan indikator: (a) adanya keterlibatan aktif dan tanggapan positif warga masyarakat terhadap kegiatan pembelajaran, dan (b) hasil belajar warga msyarakat menunjukkan terdapat peningkatan kemampuan pengetahuan, sikap dan keterampilan

\section{Saran}

Saran untuk pengelola yaitu: Pertama, pengelola PKBM disarankan untuk mengidentifikasi dan memanfaatkan potensi lingkungan di sekitar PKBM untuk meningkatkan kualitas layanan pembelajaran. Kedua, meningkatkan jalinan kemitraan dengan perusahaan (user) yang ada di wilayah PKBM, terutama untuk kepentingan: (a) penyempurnakan kurikulum PKBM yang sesuai dengan kebutuhan perusahaan sehingga lulusan PKBM dapat diserap sebagai tenaga kerja pada perusahaan yang berada di lingkungan PKBM, (b) koordinasi dengan pemerintah setempat, membahas tentang pengajuan dana corporate social responsibility (CSR) kepada perusahaan untuk digunakan seoptimal mungkin bagi 
pengembangan PKBM.

Saran untuk Dinas Pendidikan Kabupaten dan Kota yaitu: (a) melakukan pembinaan yang intensif, sehingga masalah yang dihadapi oleh pengelola PKBM dapat segera diatasi, terutama dalam hal kesulitan informasi pengajuan dana bantuan, pengadaan media belajar, dan pengadaan sarana pembelajaran; (b) mendorong dan memfasilitasi pengelola PKBM dalam mengajukan akreditasi lembaga sehingga produktifitas dan kinerja PKBM semakin baik; serta (c) memfasilitasi pembentukan Lembaga Sertifikasi Kompetensi (LSK) yang bermanfaat bagi peserta didik yang akan mengajukan uji kompetensi.

\section{DAFTAR PUSTAKA}

Anwas, O. M. (2011). Strategi pemanfaatan media pembelajaran dalam meningkatkan kompetensi penyuluh pertanian. Jurnal Teknodik, Vol. XV No. 2, Desember 2011. Jakarta: Pustekom Kemdikbud.

Ardiwinata, J. S. (2014). Peran forum PKBM dalam meningkatkan mutu pengelolaan program paudni di provinsi Jawa Tengah dan DIY. Jurnal Pedagogia, Vol. 1 No. 2, Desember 2014. Bandung: Fakultas IImu Pendidikan Universitas Pendidikan Indonesia,

Arikunto, S. (2010). Prosedur penelitian suatu pendekatan praktik. Jakarta: Rineka Cipta.

Jalal, F.,\& Supriadi, D. (2001). Pengembangan CBE dalam lapangan pendidikan. Jakarta: Depdiknas.

Hikmat, H. (2001). Strategi pemberdayaan masyarakat. Bandung: Humaniora Utama.

Hayati, L. (2011). Penerapan pendekatan pemecahan masalah melalui belajar dalam kelompok kecil untuk meningkatkan prestasi belajar pada mata kuliah teori peluang. Jurnal Teknodik, Vol. XVI. No. 2 Juni 2012. Jakarta: Pustekom Kemdikbud

Saepudin, A. (2015). Efektifitas pelatihan dan efikasi diri dalam meningkatkan perilaku berwirausaha pada masyarakat transisi. Jurnal Mimbar (Sosial dan Pembangunan), Vol. 31 No. 1. Juni 2015. Bandung: P2U LPPM UNISBA

Sudjana, D. (2001). Pendidikan nonformal, wawasan, sejarah perkembangan, falsafah, teori pendukung, azas. Bandung : Falah Production.

Sugiyono. (2012). Metode penelitian kombinasi (mixed methode). Bandung : Alfabeta.

Sihombing.,\& Gutama (2000). PKBM dalam perspektif pendidikan luar sekolah. Jakarta: Depdiknas.

Sihombing. (1999). Pendidikan luar sekolah. Jakarta: depdiknas.

Kemendikbud. Standar \& prosedur penyelenggaraan PKBM tahun 2015. Jakarta: Kementerian pendidikan dan kebudayan.

Kemendikbud. Peraturan pemerintah No.73 Tahun 1991 tentang pendidikan luar sekolah

Kemendikbud. Peraturan pemetintah No.19 Tahun 2005 tentang standar nasional pendidikan.

Undang-undang no. 20 Tahun 2003 tentang sistem pendidikan nasional.

UNESCO. (2005). International eksploratif paper. Jakarta: Depdiknas 